\title{
SEDATION OF NILE TILAPIA WITH ESSENTIAL OILS: TEA TREE, CLOVE, EUCALYPTUS, AND MINT OILS ${ }^{1}$
}

\author{
FABRÍCIO PEREIRA REZENDE ${ }^{2 *}$, LÍVIA MENDONÇA PASCOAL ${ }^{3}$, RAFAEL ALVES VIANNA $^{4}$, EDUARDO \\ ARRUDA TEIXEIRA LANNA ${ }^{4}$
}

\begin{abstract}
Essential oils have been extensively used in many commercial applications, one of them being anesthetics. The effect of four essential oils (tea tree, clove, eucalyptus, and mint oils) on the sedation, recovery, and behavioral stress of Nile tilapia (Oreochromis niloticus) was evaluated. The sedative solutions, prepared with essential oils and anhydrous ethanol (1:4), were used for fish management procedures at a dose of $7.4 \mathrm{~mL} \mathrm{~L}^{-1}$ in a completely randomized block design with four treatments and seven replicates. The means were compared using Scott-Knott test $(\mathrm{P}<0.05)$. Clove oil was found to be the most suitable oil for the immobilization of Nile tilapia; however, behavioral observations indicate that tea tree oil was the most efficient in reducing stress.
\end{abstract}

Keywords: Stress. Anesthetics. Fish. Tea tree oil. Eugenol.

\section{SEDAÇÃO DE TILÁPIA-DO-NILO COM ÓLEOS ESSENCIAIS: MELALEUCA, CRAVO, EUCALIPTO E MENTA}

RESUMO - Óleos essenciais vêm sendo intensamente utilizados em diversas aplicações comerciais, dentre elas como anestésicos. Avaliou-se o efeito de soluções com óleos extraídos de quatro tipos vegetais (melaleuca, cravo, eucalipto e menta) na sedação, na recuperação e no comportamento de estresse de tilápia-do-Nilo. Utilizaram-se soluções sedativas (óleo essencial:etanol, 1:4) na água de manejo dos peixes na dosagem de $7,4 \mathrm{~mL} / \mathrm{L}$ sob delineamento inteiramente casualizado, com quatro tratamentos e sete repetições. Os resultados foram submetidos ao teste Scott-Knott $(\mathrm{P}<0,05)$. De acordo com os resultados, o mais indicado para a imobilização de tilápia-do-Nilo é o óleo de cravo, no entanto as observações comportamentais indicam o óleo de melaleuca como o mais eficiente na redução do estresse.

Palavras-chave: Estresse. Anestesia. Peixe. Melaleuca. Eugenol.

\footnotetext{
*Corresponding author

${ }^{1}$ Received for publication in 04/29/2016; accepted in 11/16/2016

${ }^{2}$ Embrapa Pesca e Aquicultura, Palmas, TO, Brazil; fabricio.rezende@embrapa.br.

${ }^{3}$ School of Veterinary and Animal Science, Universidade Federal de Goiás, Goiânia, GO, Brazil; liviapascoal@ufg.br.

${ }^{4}$ Department of Animal Science, Universidade Federal de Viçosa, Viçosa, MG, Brazil; rafael.vianna@ufv.br, elanna@ufv.br.
} 


\section{INTRODUCTION}

The quality and sale price of fish are the two main aspects involved in consumer purchase decision. Good quality is the sum of adequate management practices during catch process, purification, transportation, and trade among the different links that connect the production and extractive chain (farmers, middlemen, wholesalers, distributors, shopkeepers, and hobbyists or producers).

During these processes, fish undergo an intense period of chronic and acute stress that compromises its vigor and physiological resistance. This leads to growth retardation and immunosuppression (ROUBACH et al., 2005; HEO; SHIN, 2010; PAWAR et al., 2011), increasing its susceptibility to infections, mortality, and parasites (GOMES et al., 2006).

The addition of anesthetic substances to water during fish management procedures, such as weighing, selection, sampling, vaccination, and transportation, aims to reduce stress, prevent physical injuries, and reduce mortality in fish (WEBER et al., 2011; ROUBACH et al., 2005). The use of such products also helps in maintaining the quality of fish (BURT, 2004; SINHA; ASIMI, 2007). The choice of anesthetics depends on several factors including cost, availability, administration protocol (CHO; HEATH, 2000; CUNHA et al., 2010; PAWAR et al., 2011), and good recovery rates.

Natural anesthetic compounds based on essential oils of plants have been used as alternatives to traditional anesthetics, primarily for fish transportation, as they are harmless to the environment, do not pose any risks to the health of the producer, and do not require veterinary prescription for marketing and use (KEENE et al., 1998).

The growing demand for fish such as Nile tilapia (Oreochromis niloticus), one of the most produced species in Brazil, necessitates the use of appropriate substances that are simple and reliable for the handling and transportation of fish with as minimum stress as possible.

This study was based on the characterization of the effects of clove, tea tree, eucalyptus, and mint oils on the behavior and sedation of Nile tilapia, in order to point out the possibility of considering its application for the handling and transportation of fish.

\section{MATERIAL AND METHODS}

Experimental conditions. The study was conducted in June 2011 at the Laboratory of Fish Nutrition, Department of Animal Science, Universidade Federal de Viçosa (DZO/UFV), in the municipality of Viçosa, Minas Gerais, Brazil. The fish were collected from a fish farm and were acclimatized for 22 days in a recirculation system with water filtration.

Experimental design. This experiment was conducted under a completely randomized design block with four treatments and seven replicates. The treatments include the four aqueous anesthetic solutions based on the essential oils such as tea tree, clove, eucalyptus, and mint oils.

Pre-experimental management. The water used in the trial, which presented an average temperature of $23.8 \pm 0.4^{\circ} \mathrm{C}$ and $\mathrm{pH}$ of $6.8 \pm 0.1$, was the same as that used in the recirculation system, where the fish were initially acclimatized. The experimental units consisted of four aquaria with volume of $4 \mathrm{~L}$ filled with Nile tilapia juveniles. A total of 28 Nile tilapia juveniles weighing $24.1 \pm 3.8 \mathrm{~g}$ were used for a stocking density of 0.25 fish $\mathrm{L}^{-1}$. Juveniles used in the trial were sexually reverted to males.

During the pre-experimental management, the fish were made to go through a fasting period of $24 \mathrm{~h}$, in order to empty their digestive tracts. This process called depuration is routinely used by fish farmers to improve conditions during handling and transportation of fish.

Sedatives. The sedative solutions were prepared with the essential oils and anhydrous ethanol at a ratio of $1: 4$ and used at a dose of $7.4 \mathrm{~mL} \mathrm{~L}^{-1}$ with water. The density of anhydrous ethanol $\left(99.5^{\circ}\right)$ was $0.789 \mathrm{~g} \mathrm{~cm}^{-3}$, tea tree oil was $0.898 \mathrm{~g} \mathrm{~cm}^{-3}$, clove oil was $1.030 \mathrm{~g} \mathrm{~cm}^{-3}$, eucalyptus oil was $0.956 \mathrm{~g} \mathrm{~cm}^{-3}$, and mint oil was $0.895 \mathrm{~g} \mathrm{~cm}^{-3}$. The dose of $7.4 \mathrm{~mL} \mathrm{~L}^{-1}$ of all anesthetic solutions used corresponded to $1,200 \mathrm{ppm}$ for tea tree oil, 1,239 ppm for clove oil, 1,217 ppm for eucalyptus oil, and 1,199 ppm for mint oil. The doses were definite from preliminary test using clove oil for sedation of numerous Nile tilapia juveniles.

Sedation and behavior. The effect of the four anesthetics was evaluated based on two parameters such as duration of action (sedation and recovery) and performance (characteristics that indicate stress). Behavioral changes based on time of action were considered during evaluation. Fish were placed one at a time in each of the four aquaria, and the time required to reach stage 5 of the sedation scale (SUMMERFELT; SMITH, 1990) was recorded. Stage 5 of the sedation cycle corresponds to the period when the movement of the fish's mouth, operculum, and fins stops and it loses its equilibrium. After retaining the fish for $10 \mathrm{~s}$ at this stage, they were photographed and transferred to another $4 \mathrm{~L}$ aquarium, with water without anesthetic solutions, and the time required for full recovery from the anesthesia was recorded.

During the sedation and recovery phases, fish behavior was monitored to indicate stress and discomfort when they were subjected to treatment 
with anesthetic solutions. An extra assessment based on the additional behavioral changes that indicate stress could be relevant; however, behavioral responses associated with essential oils were unknown. Behavioral changes such as bristling fins, changes in skin color and pattern, and changes in swimming pattern were registered as consequences of the exposure of fish to different anesthetic solutions (Table 1).

Table 1. Behavioral changes observed in response to additional stress during sedation stages.

\begin{tabular}{|c|c|c|c|c|c|}
\hline Behavioral category & & & nge & & From the stage \\
\hline Skin color & Normal & Lighter & Darker & Vertical bars & $1,2,3,4$ or 5 \\
\hline Fins & Normal & Retracted & Bristled & - & $1,2,3,4$ or 5 \\
\hline Swimming & Normal & Erratic & Spasms & - & $1,2,3,4$ or 5 \\
\hline
\end{tabular}

Photographic record. Fish were photographed during the sedation phases in order to compare changes in skin color and pattern. Based on the photographs, it was possible to quantify the degradation of dark skin tone in RGB color system, which corresponds to the superposition of the colors Red (R), Green (G), and Blue (B).

Statistical analyzes. The anesthesia period, recovery time, and changes in skin color and pattern were submitted to the presupposition test for assumption of normality (Shapiro-Wilk test) and homoscedasticity (Bartlett's test) for residues, analysis of variance (ANOVA), and subsequently the Scott-Knott test at 5\% probability (R CORE TEAM, 2013). The other behavioral changes (bristling fins and changes in swimming pattern) were evaluated using descriptive statistics.

\section{RESULTS AND DISCUSSION}

\section{Use of essential oils in fish sedation}

Because of the lack of available information on the use of essential oils for fish sedation, the present study was conducted to evaluate the sedative potential of the four compounds and their effects on fish behavior as an indicator of stress. Considering the use of the four essential oils in the present study, it can be affirmed that all of them have the ability to inhibit the movements of fish (Table 2). However, it was clear that eucalyptus, mint, and clove oils also impede movement, but behavioral responses to them still indicate that they do not inhibit stress.

Essential oils have been used for sedation of different species of fish, which include clove oil for black bass (Micropterus salmoides) (COOKE et al., 2004), tilapia (SIMÕES et al., 2012; RIBEIRO et al., 2015), pacu (ROTILI et al., 2012), chinook-salmon (Oncorhynchus tshawytscha) (CHO; HEATH, 2000), Pimephales promelas (PALIĆ et al., 2006), American-catfish (Ictalurus punctatus) (SMALL, 2003), Sparus aurata, trout (Oncorhynchus mykiss) (TORT et al., 2002; KEENE et al., 1998), Salmo trutta, Salmo salar, Coregonus lavaretus, Perca fluviatilis, and Rutilus rutilus (HOSKONEN; PIRHONEN, 2004); and mint oil for bass-arrow (Centropomus parallelus) (SOUZA et al., 2012), tambaqui (FAÇANHA; GOMES, 2005), and spotted-sorubim (Pseudoplatystoma reticulatum) (SANCHEZ et al., 2014).

For most of the species, the availability of information on doses and serological and behavioral changes by species remains incomplete in order to support recommendations for the use of essential oils as safe natural sedatives; however, clove oil has already been routinely used in research management and commercially in aquaculture enterprises.

\section{Essential oils and traditional anesthetics in fish behavior}

Fish exposed to anesthetic solutions of the four essential oils, diluted in the ratio 1:4 in ethanol, presented different sedation times and recovery periods (Table 2).

Table 2. Sedation times and recovery periods of Nile tilapia juveniles using anesthetic solutions of the four essential oils.

\begin{tabular}{lcc}
\hline Sedative solution & Time (seconds) to sedation & Time (seconds) to recovery \\
\hline Tea tree oil & $275 \pm 67 \mathrm{c}$ & $367 \pm 94 \mathrm{~b}$ \\
\hline Clove oil & $117 \pm 64 \mathrm{~d}$ & $1268 \pm 463 \mathrm{a}$ \\
\hline Eucalyptus oil & $1231 \pm 258 \mathrm{a}$ & $1260 \pm 351 \mathrm{a}$ \\
\hline Mint oil & $528 \pm 188 \mathrm{~b}$ & $536 \pm 176 \mathrm{~b}$ \\
\hline
\end{tabular}

According to the Scott-Knott test $(\mathrm{P}<0.05)$, the means followed by the same letter in the column did not differ significantly from each other.

Clove oil showed the best result, considering the shortest period necessary for fish sedation, but it showed a longer recovery period than the other treatments. The tea tree oil had the second faster sedation period, but it showed the shortest recovery period (Table 2). It also provided the best behavioral responses, indicating that it is the most effective in reducing stress while the fish are kept sedated 
(Tables 3 and 4).

Additionally, fish were monitored for the different patterns of behavior towards exposure to sedative compounds from the time they were removed from the sedative solution until full recovery.

Five behavioral changes were observed as a result of the exposure to sedative compounds. The behavioral changes observed were as follows: 1) bristling fins, indicating stress; 2) changes in the skin color and pattern with alternating dark and light vertical bands, indicating stress while threatened; 3 ) uniform color change from light to darker shades, indicating interference in the environment perception capacity as a result of sedation; 4) changes in the swimming pattern with sudden movements, indicating irritation and discomfort from exposure to sedatives; and 5) changes in swimming pattern with lethargy, indicating progress in sedation. Behavioral changes were observed from the onset of every stage of sedation. It was found that the intensity of the stimuli was progressive until the fifth stage of sedation, but some stimuli appear to have maximum intensity even at the intermediate stages. All the behavioral changes registered are shown in Table 3. These behavioral stimuli regressed when the fish were transferred to water without sedatives.

Table 3. Behavioral changes in Nile tilapia juveniles subjected to thee four anesthetic solutions of essential oils.

\begin{tabular}{|c|c|c|}
\hline Sedative solution & $\begin{array}{c}\text { Stage of } \\
\text { predominant } \\
\text { behavioral } \\
\text { change }\end{array}$ & Behavioral changes \\
\hline \multirow[t]{3}{*}{ Tea tree oil } & 5 & Does not alter the pattern and color of skin; \\
\hline & 4 & Alters the swimming pattern with lethargy, indicating progress in sedation; \\
\hline & - & Promising use as a sedative in aquaculture. \\
\hline \multirow[t]{3}{*}{ Clove oil } & 4 & Changes the color from light to darker shades, indicating stress; \\
\hline & 4 & Changes the swimming pattern with lethargy, indicating progress in sedation; \\
\hline & - & Promising use as a sedative in aquaculture. \\
\hline \multirow[t]{4}{*}{ Eucalyptus oil } & 4 & Bristling fins, indicating stress and discomfort up to stage 4 of sedation; \\
\hline & 2 & $\begin{array}{l}\text { Changes the color and pattern with alternating vertical bands of dark and light } \\
\text { shades, indicating stress; }\end{array}$ \\
\hline & 4 & $\begin{array}{l}\text { Changes the swimming pattern with sudden movements, indicating discomfort and } \\
\text { irritation from exposure to the compounds up to stage } 4 \text { of sedation; }\end{array}$ \\
\hline & - & Does not show promising use as a sedative in aquaculture. \\
\hline \multirow[t]{4}{*}{ Mint oil } & 3 & Bristling fins, indicating stress and discomfort up to stage 3 of sedation; \\
\hline & 3 & $\begin{array}{l}\text { Changes the color and pattern of the skin subtly with alternating vertical bands of } \\
\text { light and dark shades; }\end{array}$ \\
\hline & 2 & $\begin{array}{l}\text { Alters the swimming pattern with sudden movements, indicating discomfort from } \\
\text { exposure to the compounds up to stage } 2 \text { of sedation; }\end{array}$ \\
\hline & - & Does not show promising use as a sedative in aquaculture. \\
\hline
\end{tabular}

Differences in fish skin color during sedation with anesthetic solutions containing the four essential oils are presented in Figure 1.

Despite leading to a darkening in skin color, clove oil provides a faster sedation process and a longer period of recovery that make it a very promising sedative in handling live fish and potentially its transportation.

The tea tree oil provides faster sedation process, followed by rapid recovery. However, it did not show any changes in fish behavior indicating stress. Thus, there is a strong indication that the use of tea tree oil would be the best alternative to sedate fish for handling, but its addition with clove oil should be further evaluated to identify positive synergistic effects during fish sedation and transportation.

Fish maintained in water with eucalyptus oil showed adverse behaviors such as bristling fins up to stage 4 of sedation. They also showed changes in the skin color and pattern with alternating vertical bands of dark and light shades, indicating irritation and discomfort. Such behavioral characteristics indicate stress in fish (VAN DER SALM et al, 2006; BARRETO; VOLPATO, 2006). Despite the changes in swimming performance, the fish clearly showed response to the stress stimulus, even when sedated. Thus, it is possible to affirm that eucalyptus oil showed no advantages to be used as a sedative.

Fish maintained in water with mint oil presented bristling fins, indicating stress (up to stage 3 of sedation); and changes in skin color pattern, indicating irritation and discomfort due to sedation. In addition, fish showed changes in swimming pattern with sharp movements, also indicating discomfort from the exposure to the sedatives (up to stage 2 of sedation). 


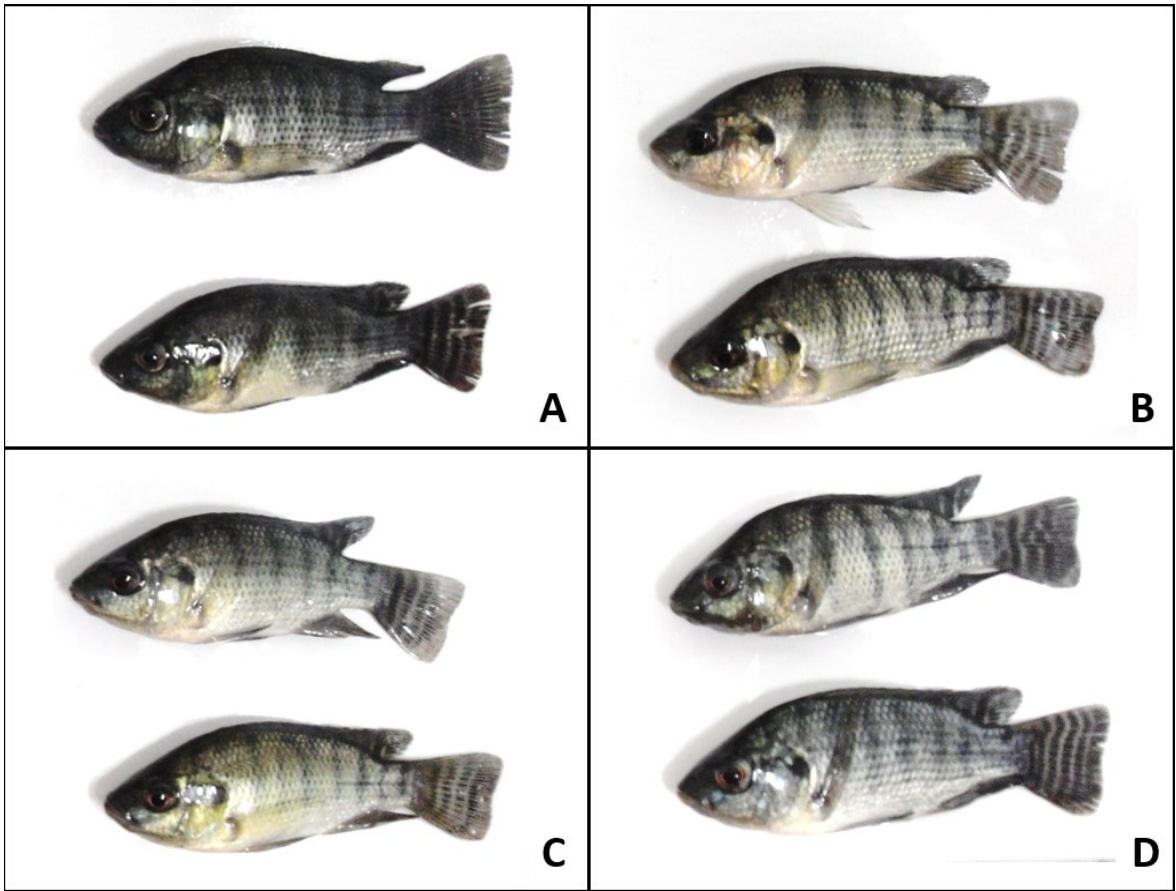

Figure A: clove oil; Figure B: eucalyptus oil; Figure C: tea tree oil; and Figure D: mint oil. According to the Scott-Knott test $(\mathrm{P}<0.05)$, means followed by the same letter do not differ significantly from each other, making it possible to observe that fish sedated with clove oil presented skin darkening effect (Table 3).

Figure 1. Changes in fish skin color during sedation with anesthetic solutions containing the four essential oils, indicating stress.

Table 4. Changes in fish skin color observed with the degradation of colors in RGB channels during sedation with anesthetic solutions containing the four essential oils.

\begin{tabular}{lccc}
\hline Sedative solution & $\mathrm{R}$ & $\mathrm{G}$ & $\mathrm{B}$ \\
\hline Tea tree oil & $79.4 \pm 9.0 \mathrm{~b}$ & $78.9 \pm 9.6 \mathrm{~b}$ & $72.7 \pm 9.0 \mathrm{~b}$ \\
Clove oil & $57.5 \pm 8.6 \mathrm{a}$ & $57.0 \pm 8.5 \mathrm{a}$ & $54.1 \pm 9.0 \mathrm{a}$ \\
Eucalyptus oil & $81.6 \pm 14.6 \mathrm{~b}$ & $79.6 \pm 13.5 \mathrm{~b}$ & $73.3 \pm 14.5 \mathrm{~b}$ \\
Mint oil & $84.3 \pm 11.0 \mathrm{~b}$ & $83.5 \pm 10.0 \mathrm{~b}$ & $79.1 \pm 10.6 \mathrm{~b}$ \\
\hline
\end{tabular}

According to the Scott-Knott test $(\mathrm{P}<0.05)$, means followed by the same letter do not differ significantly from each other.

Considering behavioral characteristics exhibited by fish, it could be observed that two of the compounds, namely eucalyptus oil and mint oil, allow sedation but without effectively reducing stress.

The clove oil anesthetic solution presents seven of the eight criteria used to define the ideal anesthetic; moreover, it presents low cost and no sanitary restrictions related to fish and human health (KEENE et al., 1998). This feature is inherent in all essential oils tested in this study.

Studies have shown the use of clove oil as an anesthetic for fish and as an alternative to traditional anesthetics used when handling and transporting fish (OLIVEIRA et al., 2009), considering that it is a natural oil with low cost, safe to use, does not leave residues in meat and in the environment, and has no toxicity to humans (CHO; HEATH, 2000; COOKE et al., 2004; PALIĆ et al., 2005; INOUE et al., 2011;

\section{SIMÕES et al., 2012).}

According to Bosworth et al. (2007), although a dosage of 1,239 ppm of clove oil is used for fish sedation, it is noteworthy that the persistence of the residues in fish should be minimal, providing a very light sensory perception in the newly harvested fish meat, in order to be used for consumption, as verified in catfish. Clove oil up to a level of $1,500 \mathrm{ppm}$ is safe for humans. This provides it a large safety margin to be used as a sedative in fish farming, (KEENE et al., 1998).

Dosages of 5 to $9 \mathrm{mg} \mathrm{L}^{-1}$ provided the best sedative effects for black bass, resulting in reduced heart rate, equilibrium, and rapid recovery of fish after being transferred to clean water (COOKE et al., 2004). Its use was satisfactory for Nile tilapia larvae and juveniles (RIBEIRO et al., 2015) and also for pacu (ROTILI et al. 2012).

Clove oil can be an effective, low-cost 
alternative compared to tricaine, because it does not need any waiting period between its use and fish consumption and does not cause environmental impacts. The blood cortisol levels, glucose concentration, hematocytes, lysozyme activity, and leukocyte content in chinook-salmon (Oncorhynchus tshawytscha) did not present significant changes before, during, immediately after recovery, and $72 \mathrm{~h}$ after recovery from the anesthesia $(\mathrm{CHO}$; HEATH, 2000).

Some authors have observed positive effects of eugenol in reducing post-sedation plasma levels compared to the traditional anesthetics such as metomidato, tricaine, and quinaldine (SMALL, 2003). Clove oil does not block the stress cortisol response in rainbow trout (TORT et al., 2002); however, there was no change in blood cortisol levels in catfish (SMALL, 2003). The blood glucose levels are similar in tambaqui after using eugenol or benzocaine (ROUBACH et al., 2005). Thus, it becomes evident that clove oil provides an efficient immobilizing activity in fish without effective sedation and stress reduction. However, it was noted that the use of clove oil as repeated anesthesia in rainbow trout has a negative effect on its growth (HOSKONEN; PIRHONEN, 2006).

The sedation time is also related to fish size and water temperatures. Smaller fish are anaesthetized quickly than larger ones, and the time to recover from anesthesia after transferring fish to clean water is higher in lower temperature of water (HOSKONEN; PIRHONEN, 2004).

The use of clove oil is safer for the producer, and it is considered to be the best for fish recovery in some species compared to tricaine (HOSKONEN; PIRHONEN, 2004). Corroborating this information, sedation with eugenol was considered similar to tricaine and promising to be used in Hippocampus kuda (PAWAR et al, 2011). Positive effects were observed in the use of benzocaine, eugenol, and menthol in sedation of fat-snook (Centropomus parallelus), highlighting the benefit and cost of eugenol (SOUZA et al, 2012). Positive effects of the use of eugenol were also observed in Brycon hilarii sedation (FABIANI et al., 2013).

The tea tree oil has three major compounds, namely, 1,8-cineole (used as a bronchodilator, an expectorant, and antiseptic), terpinen-4-ol (used in cosmetics industry), and methyl-eugenol (widely used in food industry) in its composition (CARSON; HAMMER; RILEY, 2006; LEE et al, 2013).

Fish under the effect of tea tree oil solution did not have changes in the skin color and showed no changes in swimming behavior during sedation. Despite sedating the fish, tea tree oil maintained their normal coloration and behavior without any sudden changes. The sedation process was relatively fast, but recovery was also faster. The rapid recovery of fish after sedation with tea tree oil solution highlights its advantages to be used as sedative during transportation.

It was noticed that tea tree oil and clove oil, compared to the different sedatives tested, presented the most suitable characteristics for fish from sedation to recovery.

Regarding the fish behavior and the time required for full sedation and complete recovery, the clove oil solution presented the most effective characteristics for the immobilization, allowing deep sedation in less time, while the total reflex recovery was faster when fish were immersed in a solution containing tea tree oil.

The use of eucalyptus and mint oil provided adverse behaviors such as bristling fins for a long period and changes in skin pigmentation pattern, indicating stress in fish. Hence, it should not be recommended for sedation during fish transportation or handling. However, mint oil has been indicated as an anesthetic for tropical fish as tambaqui (FAÇANHA; GOMES, 2005), fat-snook (SOUZA et al., 2012), and sorubim (SANCHEZ et al., 2014).

The use of essential Lippia alba oil has also been reported as effective in the sedation of jundia (CUNHA et al., 2010), taking into account the fungicidal action (GLAMOČLIJA et al., 2011) and the anesthetic effect of this compound, considering a new option to be tested for commercial use.

\section{Essential oils best suited for use in aquaculture}

Clove oil was the best compound regarding the time for sedation and recovery, while tea tree oil was the best in terms of stress behavior. Clove oil presented best results for complete anesthesia of Nile tilapia during management procedures. Both the compounds can also be used for other species with the aim of improving the quality of fish, thereby enabling higher profitability in the fish market and benefits to the entire production chain.

The tea tree oil has favorable characteristics to be used as sedative during transportation, since it is effective in avoiding stress and enables quick recovery of fish when transferred to clean water.

Among the additional advantages of the use of sedatives are stress reduction, ease of handling, use of higher quantity of fish per package, and prolongation of the transportation time. This reduces the need for fish repackaging during longer journeys, contributing to lower costs and reduction in mortality during commercialization and storage in after-sales warehouses.

Thus, the development of relevant technologies using a combination of tea tree oil and clove oil would present positive results in commercial-scale aquaculture enterprises. This would enable an increase in the management efficiency during fish transportation, thereby reducing the costs and providing products of best quality. 


\section{CONCLUSIONS}

Thus, tea tree oil at a dose of $7.4 \mathrm{~mL} \mathrm{~L}^{-1}$ $(1,200 \mathrm{ppm})$ was more efficient and the most suitable for sedation of fish packed for transportation, since it does not change the behavior, indicating stress in fish. Clove oil at a dose of $7.4 \mathrm{~mL} \mathrm{~L}^{-1}(1,239 \mathrm{ppm})$ was more effective for fish immobilization during management, suggesting it to be the most suitable sedative compound due to its longer recovery time during fish handling.

\section{REFERENCES}

BARRETO, R. E.; VOLPATO, G. L. Stress responses of the fish Nile tilapia subjected to electroshock and social stressors. Brazilian Journal of Medical and Biological Research, Ribeirão Preto, v. 39, n. 12, p. 1605-1612, 2006.

BOSWORTH, B. G. et al. Effects of rested-harvest using the anesthetic AQUI-STM on channel catfish, Ictalurus punctatus, physiology and fillet quality. Aquaculture, Amsterdam, v. 262, n. 2-4, p. 302$318,2007$.

BURT, S. Essential oils: their antibacterial properties and potential applications in foods - a review. International Journal of Food Microbiology, Washington, v. 94, n. 4, p. 223-253, 2004.

CARSON, C. F.; HAMMER, K. A.; RILEY, T. V. Melaleuca Alternifolia (Tea Tree) Oil: A Review of Antimicrobial and Other Medicinal Properties. Clinical Microbiology Reviews, Minnesota, v. 19, n. 1, p. 50-62, 2006.

CHO, G. K.; HEATH, D. D. Comparison of tricaine methanesulphonate (MS222) and clove oil anaesthesia effects on the physiology of juvenile Chinook salmon Oncorhynchus tshawytscha (Walbaum). Aquaculture Research, Oxford, v. 31, n., p. 537-546, 2000.

COOKE, S. J. et al. Behavioral and physiological assessment of low concentrations of clove oil anaesthetic for handling and transporting largemouth bass (Micropterus salmoides). Aquaculture, Amsterdam, v. 239, n. 1-4, p. 509-529, 2004.

CUNHA, M. A. et al. Short communication Essential oil of Lippia alba: A new anesthetic for silver cat fish, Rhamdia quelen. Aquaculture, Amsterdam, v. 306, n. 1-4, p. 403-406, 2010.

FABIANI, B. M. et al. Benzocaine and eugenol as anesthetics for Brycon hilarii. Acta Scientiarum. Animal Sciences, Maringá, v. 35, n. 2, p. 113-117, 2013.
FAÇANHA, M. F.; GOMES, L. C. A eficácia do mentol como anestésico para tambaqui (Colossoma macropomum, Characiformes: Characidae). Acta Amazonica, Manaus, v. 35, n. 1, p. 71-75, 2005.

GLAMOČLIJA, J. et al. Chemical characterization of Lippia alba essential oil: an alternative to control green molds. Brazilian Journal of Microbiology, São Paulo, v. 42, n. 4, p. 1537-1546, 2011.

GOMES, L. C. et al. Use of salt during transportation of air breathing pirarucu juveniles (Arapaima gigas) in plastic bags. Aquaculture, Amsterdam, v. 256, n. 1-4, p. 521-528, 2006.

HEO, G. J.; SHIN, G. Efficacy of benzocaine as an anaesthetic for crucian carp (Carassius carassius). Veterinary Anaesthesia and Analgesia, Malden, v. 37, n. 2, p. 132-135, 2010.

HOSKONEN, P.; PIRHONEN, J. Effects of repeated handling, with or without anaesthesia, on feed intake and growth in juvenile rainbow trout, Oncorhynchus mykiss (Walbaum). Aquaculture Research, Oxford, v. 37, n. 4, p. 409-415, 2006.

HOSKONEN, P.; PIRHONEN, J. Temperature effects on anaesthesia with clove oil in six temperature-zone fishes. Journal of Fish Biology, Scotland, v. 64, p. 1136-1142, 2004.

INOUE, L. A. K. A. et al. Avaliação de respostas metabólicas do tambaqui exposto ao eugenol em banhos anestésicos. Acta Amazonica, Manaus, v. 41, n. 2, p. 327-332, 2011

KEENE, J. L. et al. The efficacy of clove oil as an anaesthetic for rainbow trout, Oncorhynchus mykiss (Walbaum). Aquaculture Research, Oxford, v. 29, n. 2 , p. 89-101, 1998.

LEE, C. J. et al. Correlations of the components of tea tree oil with its antibacterial effects and skin irritation. Journal of Food and Drug Analysis, Taipei, v. 21, n. 2, p. 169-176, 2013.

OLIVEIRA, J. R. et al. Cloreto de sódio, benzocaína e óleo de cravo-da-índia na água de transporte de tilápia-do-Nilo. Revista Brasileira de Zootecnia, Viçosa, v. 38, n. 7, p. 1163-1169, 2009.

PALIĆ, D. et al. Anesthetic efficacy of tricaine methanesulfonate, metomidate and eugenol: Effects on plasma cortisol concentration and neutrophil function in fathead minnows (Pimephales promelas Rafinesque, 1820). Aquaculture, Amsterdam, v. 254, n. 14, p. 675-685, 2006.

PAWAR, H. B. et al. Comparative efficacy of four anaesthetic agents in the yellow seahorse, 
Hippocampus kuda (Bleeker, 1852). Aquaculture, Amsterdam, v. 311, n. 1-4, p. 155-161, 2011.

R CORE TEAM. R: A language and environment for statistical computing. R Foundation for Statistical Computing, Vienna, Austria, 2013. Disponível em: $<$ http://www.R-project.org/>. Acesso em: 15 jan. 2016.

RIBEIRO, P. A. P. et al. Efficiency of eugenol as anesthetic for the early life stages of Nile tilapia (Oreochromis niloticus). Anuário da Academia Brasileira de Ciências, Rio de Janeiro, v. 87, n. 1, p. 529-535, 2015.

ROTILI, D. A. et al. Uso de eugenol como anestésico em pacu. Pesquisa Agropecuária Tropical, Goiânia, v. 42, n. 3, p. 288-294, 2012.

ROUBACH, R. et al. Eugenol as an efficacious anaesthetic for tambaqui, Colossoma macropomum (Cuvier). Aquaculture Research, Oxford, v. 36, n. 11, p. 1056-1061, 2005.

SANCHEZ, M. S. S. et al. Respostas fisiológicas de cacharas Pseudoplatystoma reticulatum submetidos a anestésicos naturais. Semina: Ciências Agrárias, Londrina, v. 35, n. 2, p. 1061-1070, 2014.

SIMÕES, L. N. et al. O uso do óleo de cravo como anestésico em juvenis avançados de tilápia do Nilo (Oreochromis niloticus). Acta Scientiarum. Animal Sciences, Maringá, v. 34, n. 2, p. 175-181, 2012.

SINHA, A.; ASIMI, O. A. China rose (Hibiscus rosasinensis) petals: a potent natural Carotenoid source for goldfish (Carassius auratus L.). Aquaculture Research, Oxford, v. 38, n. 11, p. 1123-1128, 2007.

SMALL, B. C. Anesthetic efficacy of metomidate and comparison of plasma cortisol responses to tricaine methanesulfonate, quinaldine and clove oil anethesized channel catfish Ictalurus punctatus. Aquaculture, Amsterdam, v. 218, n. 1-4, p. 177$185,2003$.

SOUZA, R. A. R. et al. Efeito comparativo da benzocaína, mentol e eugenol como anestésicos para juvenis de robalo peva. Boletim do Instituto de Pesca, São Paulo, v. 38, n. 3, p. 247 $\square$ 255, 2012.

SUMMERFELT, R. C.; SMITH, L. S. Anesthesia, surgery and related techniques. In: Schreck, C. B.; Moyle, P. B. (Eds.) Methods for fish biology. Bethesda, MD: American Fisheries Society, p. 213272. 1990.

TORT, L. et al. Cortisoland haematological response in sea bream and trout subjected to the anaesthetics clove oil and 2-phenoxyethanol. Aquaculture Research, Oxford, v. 33, n. 11, p. 907-910, 2002.

VAN DER SALM, A. L. et al. The acute stress response of red porgy, Pagrus pagrus, kept on a red or white background. General and Comparative Endocrinology, New York, v. 145, n. 3, p. 247-253, 2006.

WEBER, R. A. et al. Effects of acute exposure to 2-phenoxyethanol, clove oil, MS-222, and metomidate on primary and secondary stress responses in Senegalese sole (Solea senegalensis Kaup 1858). Aquaculture, Amsterdam, v. 321, n. 14, p. 108-112, 2011. 